\title{
Cervical Angiosarcoma
}

National Cancer Institute

\section{Source}

National Cancer Institute. Cervical Angiosarcoma. NCI Thesaurus. Code C128049.

A highly aggressive malignant vascular neoplasm that arises from the cervix and shows endothelial cell differentiation. 